Artur Aleksiejuk

ORCID 0000-0002-5827-6048

Chrześcijańska Akademia Teologiczna

w Warszawie

\title{
LEW TOŁSTOJ \\ - PREKURSOR PEDAGOGIKI NOWEGO WYCHOWANIA W ROSJI
}

AbSTRACT. Aleksiejuk Artur, Lew Tołstoj - prekursor pedagogiki Nowego Wychowania w Rosji [Leo Tolstoy - Precursor of New Education Pedagogy in Russia]. Studia Edukacyjne nr 57, 2020, Poznań 2020, pp. 227-240. Adam Mickiewicz University Press. ISSN 1233-6688. DOI: 10.14746/se.2020.57.16

Interest in New Education Pedagogy is currently is experiencing its renaissance. The solutions suggested by alternative education, which emphasise the development of students' individual skills and also addressing their needs and interests seem to be better suited to present times. The pedagogy of New Education, which places children in the centre of the educational and formation process, undoubtedly has much to offer. When reflecting on contemporary methods of making use of the achievements of New Education, it is worth going back to its origins, even to those little known or even forgotten and almost absent in current academic discourse as exemplified by the pedagogical reflection of the outstanding Russian intellectual and novelist, Leo Tolstoy (1828-1910). This article is dedicated to recalling the basic educational and formational intuitions of this exceptional figure. This seems to be intentional for at lease three reasons. First, as Sergiusz Hessen stated, it was Tolstoy who laid the groundwork for the New Educational pedagogy in Russia, which was referred to there as Free Education. Secondly, Leo Tolstoy's pedagogical views and initiatives in the spirit of New Education, if establishing a school in Yasnaya Polyana can be acknowledged as such, appeared almost half a century earlier than John Dewey's My Pedagogic Creed Ellen Key's The Century of the Child. Finally, and equally as important, the 190's anniversary of Leo Tolstoy's birth will be celebrated next year.

Key words: Leo Tolstoy, New Education, Free Education, Russian pedagogy of the $19^{\text {th }}$ century

Zainteresowanie pedagogiką Nowego Wychowania przeżywa obecnie swój renesans ${ }^{1}$. W konfrontacji z praktykowaną w większości instytucji kształcących dzieci i młodzież metodologią tradycyjną, rozwiązania proponowane przez pedagogikę niedyrektywną wydają się lepiej dopasowane do obecnych czasów.

${ }^{1}$ Edukacja alternatywna w XXI wieku, red. B. Śliwerski, Z. Melosik, Kraków 2013. 
Tajemnica niezmienności dążeń reformatorskich, w tym również tych, związanych $z$ ruchem alternatywnej edukacji, tkwi (...) w coraz silniej odczuwanej przez szeroko pojmowanych wychowawców potrzeby odstąpienia od odczłowieczających struktur i praktyk edukacyjnych na korzyść rzeczywistej, a nie tylko deklarowanej humanizacji procesu kształcenia i wychowania. Stąd też najprawdopodobniej tak szerokie zainteresowanie, tak wielu pedagogów, problematyką wielości dróg wiodących do edukacyjnego i wychowawczego powodzenia².

Pedagogika Nowego Wychowania, stawiająca na rozwój indywidualnych zdolności ucznia, wspierająca jego kreatywność, umiejąca dostrzec w nim twórcę, a nie tylko naśladowcę, jest tutaj bez wątpienia koncepcją wartą zainteresowania. Sprzeciwiając się przesadnemu intelektualizmowi i formalizmowi dydaktycznemu szkoły tradycyjnej, przedstawiciele ruchu Nowego Wychowania podkreślali konieczność uwzględnienia w procesie pedagogicznym właściwości duchowych i psychicznych dziecka, jego indywidualnych potrzeb i zainteresowań. $W$ ten sposób stawiając je w centrum procesu wychowania i kształcenia, wyraźnie dawano do zrozumienia, że traktowanie dziecka wyłącznie jako elementu jednakowej „uczniowskiej masy”, której przeznaczeniem jest bycie urobionym do konsystencji pożądanej i oczekiwanej przez aktualnie obowiązujący system polityki oświatowej, jest nie tylko nieskuteczne, ale nawet szkodliwe.

Mówiąc o pedagogice Nowego Wychowania, należy sięgnąć do jej początków. Warto zauważyć, że miała ona swoje różne odsłony i w odmienny sposób ją określano. W Europie, za sprawą francuskiego socjologa i pedagoga Edmunda Demolinsa (1852-1907), ruch ten nazwano Nowym Wychowaniem³. Na Starym Kontynencie używano także innych określeń, jak: pedagogika reformy, nowa szkoła, szkoła na miarę dziecka, szkoła aktywna, szkoła pracy, szkoła twórcza, szkoła życia. W Stanach Zjednoczonych Nowe Wychowanie określano zaś mianem progresywizmu4

Pierwsi przedstawiciele ruchu Nowego Wychowania nie ukrywali, że czerpali swoje inspiracje $\mathrm{z}$ naturalistycznych idei Jana Jakuba Rousseau ${ }^{5}$. Chociaż nowe idee zwiastujące powstanie nowego kierunku w pedagogice pojawiły się już pod koniec XIX wieku, najpierw w Anglii, potem zaś we

\footnotetext{
${ }^{2}$ R. Nowakowska-Siuta, Stowo wstępne, [w:] Edukacja alternatywna na rzecz demokratyzacji procesu kształcenia, red. R. Nowakowska-Siuta, Kraków 2014, s. 11-12.

${ }^{3}$ E. Demolins, Nowe wychowanie, przekł. J.W. Dawid, Warszawa 1900.

${ }^{4}$ C. Kupisiewicz, Szkota w XX wieku, Warszawa 2006, s. 31-46; S. Sztobryn, Pedagogika Nowego Wychowania, [w:] Pedagogika. Podręcznik akademicki, t. I, red. Z. Kwieciński, B. Śliwerski, Warszawa 2005, s. 281.

${ }^{5}$ S. Sztobryn, Pedagogika Nowego Wychowania, s. 286; S. Kot, Historia wychowania, t. II, Warszawa 1996, s. 10-25; J. Legowicz, Pedagogika francuskiego naturalizmu, [w:] Historia wychowania, t. I, red. Ł. Kurdybacha, Warszawa 1967, s. 612-614, 620.
} 
Francji, Szwajcarii i Niemczech ${ }^{6}$, ogromną rolę w torowaniu drogi Nowemu Wychowaniu odegrała dopiero książka autorstwa szwedzkiej pisarki i pedagog Ellen Key (1849-1926), zatytułowana Stulecie dziecka.

W sposób sugestywny - pisze Kazimierz Sośnicki - autorka głosi w niej zasadę prymatu dziecka w życiu rodzinnym i społecznym (...). Naczelnym hasłem ma się stać wolność indywidualizmu dziecka i jego swobodne wychowanie. Wszelkie środki przymusowe w jego wychowaniu: polecenia, nakazy, kary mają być usunięte na rzecz wolności i miłości dziecka. Dlatego też nie może istnieć ani systematyczna nauka, ani wychowanie religijne, ani sala szkolna. Całe wychowanie zapełnia wolna działalność dziecka, zabawa, zajęcia na polu, na boisku sportowym, w ogrodzie, w polu, w warsztacie. Wychowanie to oparte jest na poszanowaniu dziecka i jego prawa do swobodnego rozwoju?

Za sprawą tej książki, która została przetłumaczona na prawie wszystkie języki europejskie, idee Nowego Wychowania znalazły szeroki oddźwięk w społeczeństwie i środowisku pedagogów. Szerokim echem odbiły się także w Rosji, gdzie Stulecie dziecka ukazało się już w 1905 roku ${ }^{8}$, dwa lata wcześniej niż w Polsce 9 . Na jej znaczenie i popularność w Rosji wskazuje fakt, iż w latach 1905-1906 jej wydania były wielokrotnie wznawiane.

Idee Nowego Wychowania w Rosji, podobnie jak w innych krajach Europy i w Stanach Zjednoczonych, zagościły więc dopiero w pierwszej dekadzie XX wieku. Za głównego przedstawiciela i lidera tego kierunku w pedagogice rosyjskiej na początku XX wieku należy uznać Konstantego Wentcela (1857-1946), który swoje poglądy na wychowanie i kształcenie dzieci wyłożył w książce Walka o swobodna szkołę, wydaną w Moskwie w 1906 roku $^{10}$. W tym samym roku, w celu implementacji głoszonych idei pedagogicznych, wraz z grupą pedagogów podjął uwieńczone sukcesem starania o założenie w Moskwie eksperymentalnej placówki edukacyjnej Domu Wolnego Dziecka. Opublikował nawet instrukcję Jak stworzyć wolna szkołę? mającą służyć pomocą pedagogom, którzy chcieliby zakładać wolne szkoły na wzór Domu Wolnego Dziecka ${ }^{11}$. Inną ważną inicjatywą Wentcela było sformułowanie Wielkiej Karty Wolności Dziecka, „,zawierającej wszystkie niezbędne gwarancje stałego wdrażania [wolności - przyp. aut.] w dziele

${ }^{6}$ K. Sośnicki, Rozwój pedagogiki zachodniej na przełomie XIX i XX wieku, Warszawa 1967, s. $49-56$.

7 Tamże, s. 45-46.

8 Э.К.С. Кей, Век ребенка, пер. Е. Залога, В. Шахно, Москва 1905.

${ }^{9}$ E. Key, Stulecie dziecka, przekł. I. Moszczyńska, Warszawa 1907.

10 К.Н. Вентцель, Борьба за свободную школу, Москва 1906.

${ }^{11}$ К.Н. Вентцель, Как создать свободную школу (дом свободного ребенка), Москва 1906. 
wychowania i edukacji". Jego propozycja doczekała się realizacji dopiero w roku 1917 i przyjęła formę Deklaracji Praw Dziecka ${ }^{12}$.

Dzieło rozpoczęte przez Konstantego Wentcela kontynuowało i rozwijało wiele ważnych postaci rosyjskiej myśli pedagogicznej, wśród których można wymienić Iwana Gorbunow-Posadowa (1864-1940), Stanisława Szackiego (1878-1934), Pawła Błońskiego (1884-1941), Wasyla Suchomlińskiego (19181970), a nawet Lwa Wygotskiego (1896-1934). Jednakże, za prekursora Nowego (Swobodnego) Wychowania w Rosji zgodnie uznawany jest inny wybitny intelektualista, szerokiemu ogółowi znany bardziej jako wybitny powieściopisarz niż pedagog - Lew Tołstoj (1828-1910). Jego poglądy oraz inicjatywy pedagogiczne w duchu Nowego Wychowania, jeśli za takie uznać starania założenia szkoły w Jasnej Polanie na przełomie lat 1848 i 1849, niemal o pół wieku wyprzedziły zarówno ukazanie się książki Moje pedagogiczne credo autorstwa Johna Deweya ${ }^{13}$, jak i wspomnianej wyżej książki Stulecie dziecka Ellen Key. Zdaniem wybitnego, związanego z Polską, rosyjskiego pedagoga Sergiusza Hessena, to właśnie Tołstoj położył podwaliny pod gmach pedagogiki Nowego Wychowania w Rosji ${ }^{14}$. Spróbujmy zatem przyjrzeć się bliżej zapatrywaniom pedagogicznym tej wybitnej postaci i jego krytyce współczesnego mu systemu oświaty i wychowania.

Bez wątpienia, wśród bogatej i różnorodnej twórczości Lwa Tołstoja problematyka pedagogiczna zajmowała miejsce szczególne. Jego poglądy na wychowanie wywarły istotny wpływ na rosyjską myśl pedagogiczną. Artykuły publikowane przede wszystkim w założonym przez niego czasopiśmie Jasna Polana (ros. Ясная Поляна) są świadectwem wyjątkowej zdolności obserwacji procesu dydaktyczno-wychowawczego ich autora, odznaczają się subtelnością charakterystyk uczniów i dowodzą skuteczności metod oddziaływań pedagogicznych wdrażanych w założonej przez niego szkole dla dzieci wiejskich $^{15}$. Pedagogiczne zapatrywania Tołstoja na początku lat 50. XIX wieku, czyli w okresie jego usilnych starań o założenie szkoły elementarnej w należącym do niego majątku Jasna Polana, stały pod znakiem bezkompromisowo krytycznego stosunku do dominującej w ówczesnej Rosji, u schyłku epoki Mikołajewskiej (1825-1855), polityki i praktyki oświatowej. Tołstoja nie przekonały także, skądinąd postępowe jak na owe czasy, założenia reformy szkolnictwa elementarnego i średniego podjęte w 1864 roku za panowania cesarza

${ }_{12}$ К.Н. Вентцель, Борьба за свободную школу, s. 105; tenże, Отделение школы от государства и декларация праљ ребенка, Москва 1906.

13 J. Dewey, My Pedagogic Creed, New York - Chicago 1897.

14 S. Sztobryn, Filozofia wychowania Sergiusza Hessena, Łódź 1994, s. 149.

15 L. Tołstoj, Szkoła jasnopolańska w miesiącu listopadzie i grudniu, [w:] L. Tołstoj, Pisma pedagogiczne, przekł. L. i S. Wołoszynowie, Wrocław - Warszawa - Kraków 1963, s. 126-222. 
Aleksandra $\mathrm{II}^{16}$. W piśmie Ministra Spraw Wewnętrznych i Sprawiedliwości do Ministra Oświecenia Publicznego z 3 października 1862 roku, mającym uzasadnić zamknięcie czasopisma Jasna Polana, czytamy:

Uważna lektura czasopisma pedagogicznego "Jasna Polana”, wydawanego przez hrabiego Tołstoja, uzasadnia przekonanie, że czasopismo to głosi zupełnie nowe zasady nauczania i podstawy szkolnictwa ludowego, nierzadko rozpowszechnia takie idee, które prócz tego, że są niesłuszne, są również szkodliwe dzięki swej tendencji. (...) Uważam za właściwe zwrócić uwagę (...) na ogólny kierunek i duch tego czasopisma, często obalającego podstawowe zasady religii i moralności. Kontynuowanie tego czasopisma $\mathrm{w}$ tym samym duchu powinno być uznane, moim zdaniem, za szkodliwe (...). Szkodliwość właśnie polega na fałszywości i ekscentryczności tych przekonań, które będąc ujęte ze szczególną swobodą, mogą wciągnąć na tę drogę nieuświadomionych pedagogów i nadać zgoła niewłaściwy kierunek sprawie oświaty ludowej ${ }^{17}$.

W artykułach publikowanych w wydawanym przez siebie czasopiśmie Tołstoj poddawał ostrej krytyce przede wszystkim założenia ówczesnej pedagogiki. W artykule $O$ oświacie ludowej z 1862 roku pisał:

Wszystkie teorie pedagogiczno-filozoficzne mają za cel i zadanie wykształcenie ludzi cnotliwych (...). Lecz na pytanie: czego i jak winno się uczyć lud, żadna teoria nie daje odpowiedzi pewnej. Jeden twierdzi to, drugi owo, a im dalej, tym sądy te zawierają coraz więcej sprzeczności. (...) Wnikając w historię filozofii pedagogiki, znajdziemy w niej nie kryterium wykształcenia, lecz przeciwnie - pewną myśl ogólną, (...) co utwierdza nas w przekonaniu, że kryterium takiego w ogóle nie ma. (...) Określenie pedagogiki i jej celu w sensie filozoficznym jest niemożliwe, bezcelowe i szkodliwe ${ }^{18}$.

Tołstoj postuluje więc porzucenie abstrakcyjnych teorii, na których opiera się pedagogika i wybór drogi doświadczenia. W artykule O społecznej działalności na polu oświaty ludowej stwierdza: „Głównym środkiem nabycia wiedzy jest bezpośredni stosunek do zjawisk życia"19, czym wyraźnie daje do zrozumienia, że rozwój pedagogiki jest możliwy jedynie przez realne doświadczenie życiowe. W poszukiwaniu nowych dróg rozwoju pedagogiki Tołstoj szczególnie podkreślał związek teorii pedagogicznej z praktyką szkolną. Uważał, że należy gromadzić doświadczenia pedagogiczne i testować w praktyce różne metody nauczania. To bowiem „życie dostarcza pojęć - pisał - szkoła zaś harmonizuje je i ujmuje w system” ${ }^{20}$. Dlatego postulował,

${ }^{16}$ N.K. Gonczarow, Oświata $i$ wychowanie w Rosji na początku drugiej połowy XIX w., [w:] Historia wychowania, t. II, s. 477-484.

17 А.Г. Фомин, Педагогическая деятельность Л.Н. Толстого, [w:] Л.Н. Толстой, Педагогические сочинения, С.-Петербург 1912, s. 26.

${ }^{18}$ L. Tołstoj, O oświacie ludowej, [w:] L. Tołstoj, Pisma pedagogiczne, s. 19-20, 35.

${ }^{19}$ L. Tołstoj, O społecznej działalności na polu oświaty ludowej, [w:] Tamże, s. 267.

${ }^{20}$ Tamże, s. 265. 
aby szkoła była swego rodzaju laboratorium. Tylko wtedy, gdy doświadczenie praktyczne będzie podstawą pracy szkoły, wówczas nie pozostanie ona w tyle postępu ogólnego ${ }^{21}$.

W kwestii wychowania i wykształcenia Tołstoj stał zatem na stanowisku rozdzielenia tych dwóch sfer oddziaływania na młodego człowieka.

Wychowanie - pisze Tołstoj w artykule Wychowanie $i$ wyksztatcenie - nie jest przedmiotem pedagogiki, ale jednym ze zjawisk, na które pedagogika nie może nie zwrócić uwagi; przedmiotem zaś pedagogiki musi i może być tylko kształcenie ${ }^{22}$.

Może ono jednak wspierać lub przeszkadzać w kształceniu. Wychowanie sprzyjające kształceniu to takie, które zachęca wychowanka do nawiązywania relacji z realnym światem, a nie odgradza go od świata „chińskim murem książkowej mądrości"23. Dominujący w Rosji system wychowawczy ocenia jako opresyjny, nieliczący się z zainteresowaniami i potrzebami wychowanka, oparty na przymusie i mający zadośćuczynić potrzebom nauczyciela-wychowawcy, który jest urzędnikiem realizującym interes państwa. W tym upatruje przyczyn niewydolności i nieskuteczności systemu oświaty.

Wychowawca - stwierdza - stara się odgrodzić swego wychowanka od wpływów świata, nieprzebytym murem (...). Wpływ życia przestał być wszędzie troską pedagoga (...), przez który przepuszcza się kształtujący wpływ życia tylko w takim zakresie, w jakim chcą wychowawcy. Nie uznaje się wpływu życia ${ }^{24}$.

W innym miejscu zaś stwierdza:

Nie wiem, czym winno być wykształcenie i wychowanie, nie uznaję całej filozofii pedagogiki, ponieważ neguję, ażeby człowiek mógł wiedzieć, co wiedzieć mu potrzeba. Wykształcenie i wychowanie pojmuję jako historyczne fakty oddziaływania jednych ludzi na drugich; stąd zadaniem nauki o kształceniu jest - według nas tylko wykrycie praw tego oddziaływania jednych ludzi na drugich. Nie tylko nie przypisuję naszemu pokoleniu wiedzy i nie tylko nie uznaję prawa do tego, aby wiedzieć, co potrzeba młodemu pokoleniu. Jestem przekonany, że świadomość dobra i zła tkwi w całej ludzkości, niezależnie od woli człowieka i że rozwija się nieświadomie razem z historią; że nie można młodemu pokoleniu ani zaszczepić tej naszej świadomości na drodze kształcenia, ani pozbawić go tej świadomości (...). Nasza domniemana wiedza o prawach dobra i zła i oparte na niej oddziaływanie na młode pokolenie - to przeważnie przeciwdziałanie rozwojowi nowej świadomości,

${ }^{21}$ L. Tołstoj, Postęp a definicja wyksztatcenia, [w:] L. Tołstoj, Pisma pedagogiczne, s. 284-315; tenże, Ogólne uwagi dla nauczyciela, [w:] Tamże, s. 242-246.

${ }^{22}$ L. Tołstoj, Wychowanie a wyksztatcenie, [w:] Tamże, s. 227.

${ }^{23}$ Tamże, s. 226.

${ }^{24}$ Tamże, s. 226-227; S. Hessen, Podstawy pedagogiki, przekł. A. Zieleńczyk, Warszawa 1997, s. 91 . 
nie ukształtowanej jeszcze przez nasze pokolenie, a kształtujące się w młodym pokoleniu - to przeszkoda, a nie pomoc dla oświaty ${ }^{25}$.

\section{Dlatego}

wymagać, aby wychowankowie nauczyli się tego czy innego, wykształcili się tak, jak sami rozumiemy wykształcenie - nie jest możliwe; tak samo niemożliwe jest, aby stali się oni moralni w naszym rozumieniu tego słowa. Ale całkowicie możliwe jest, aby samemu nie brać udziału w wypaczaniu dzieci (...), ale całym swym życiem i w miarę swoich sił oddziaływać na nie, zarażając przykładem dobra ${ }^{26}$.

Przez większość swego życia Tołstoj opowiadał się za radykalną separacją wychowania i edukacji. Warto podkreślić, że pod koniec życia zrewidował jednak swoje poglądy w tym względzie i w Liście do W.F. Bułgakowa o wychowaniu napisał:

Rozgraniczenie, jakie wprowadziłem między wychowaniem a kształceniem (...) jest sztuczne. Wychowanie i kształcenie są nierozłączne. Nie można wychowywać, nie przekazując wiedzy, każda zaś wiedza działa wychowawczo ${ }^{27}$.

Jednakże, nie krytyka systemu oświaty i wychowania w Rosji za panowania cesarzy Mikołaja I i Aleksandra II ani postulowane oddzielenie wychowania od kształcenia w procesie pedagogicznym, ani nawet zapatrywania aksjologiczne uczyniły Tołstoja pionierem Nowego Wychowania, które w Rosji było określane mianem Wychowania Swobodnego. Lew Tołstoj został uznany za prekursora tego kierunku dlatego, że wolność uznał za naczelne hasło swojej koncepcji pedagogicznej.

Działalność oświecanego jak i oświecającego ma jeden i ten sam cel. Zadaniem nauki o kształceniu jest poznawanie warunków zbieżności tych dwóch dążeń przy jednym wspólnym celu i wskazywanie warunków przeszkadzających tej zbieżności. (...) Musimy poznawać wszystkie warunki, które sprzyjają zbieżności dążeń pouczającego i pouczanego; musimy określić, czym jest ta wolność, której brak stanowi przeszkodę w zbieżności obu dążeń i która sama jest dla nas kryterium całej nauki o kształceniu ${ }^{28}$.

Według Tołstoja, wolność jest właściwością ludzkiej natury, czyli jej przyrodzoną i niezbywalną wartością. Wszystko co człowieka zniewala jest zaś złem i do złego prowadzi. Troska o wolność należy do podstawowych praw

${ }^{25}$ L. Tołstoj, O oświacie ludowej, s. 35-36.

${ }^{26}$ L. Tołstoj, Rola przykładu i naśladownictwa w wychowaniu, [w:] L. Tołstoj, Pisma pedagogiczne, s. 418-419.

${ }^{27}$ L. Tołstoj, O wychowaniu (odpowiedź na list W.F. Bułgakowa), [w:] Tamże, s. 426,

${ }^{28}$ L. Tołstoj, O oświacie ludowej, s. 36. 
i obowiązków człowieka, który jest istotą rozumną (ros. разумное существо). Dobrostan wolnej rozumnej świadomości (ros. свободное разумное сознание) jest konstytutywnym warunkiem rozwoju człowieka. Jeśli coś przeszkadza w jej rozwoju, a za takie krępujące wolność czynniki uważał Tołstoj stosunki polityczne i ekonomiczne, życie człowieka staje się niemoralne i pozbawione sensu. Dlatego, naczelnym kryterium powodzenia w procesie edukacji, który w założeniu ma służyć dobru człowieka i promować jego rozwój, powinna być wolność. W cytowanym wyżej liście $O$ wychowaniu Tołstoj pisał:

Swoboda jest koniecznym warunkiem każdego prawdziwego kształcenia zarówno dla uczących się, jak i uczących. (...) Jedynie pełna swoboda, tj. brak przymusu i bezinteresowność nauczania zarówno dla nauczanych, jak i dla uczących, wybawiłaby ludzi od większości zła, które wytwarza przyjęte wszędzie przymusowe i interesowne kształcenie ${ }^{29}$.

Analizując poglądową metodę nauczania w szkicu O społecznej dziatalności na polu oświaty duchowej czytamy:

Aby w szkole można było nabywać jak najwięcej wiadomości, stosunek uczniów do szkoły, nauczyciela i do książki powinien być tak samo swobodny, jak stosunek tychże uczniów do przyrody i do wszystkich zjawisk życiowych ${ }^{30}$.

Zdaniem Tołstoja, swoboda w procesie kształcenia jest warunkiem postępu.

Każdy krok pedagogiki naprzód, jeżeli uważnie przestudiujemy jej historię, polega jedynie na coraz to większym stopniu naturalności w stosunkach między nauczycielem a uczniami, na coraz to mniejszym przymusie i na coraz to większym ułatwieniu nauki,

pisał w Liście do J.M. Szatiłowa o oświacie ludowej31. W Liście do P.I. Biriukowa o swobodnej szkole Tołstoj natomiast podkreśla:

Tylko przy pełnej swobodzie można doprowadzić najlepszych uczniów do tych granic, do których dojść mogą (...). Tylko przy zachowaniu swobody można uniknąć pospolitego zjawiska: wstrętu do przedmiotów, które w odpowiednim czasie i przy zachowaniu swobody mogłyby być lubiane. Tylko w atmosferze swobody można się dowiedzieć, do której specjalności uczeń ma skłonność, tylko swoboda nie zakłóca procesu wychowawczego. (...) Wiem, że to trudne, ale cóż robić, jeśli się zrozumie, że każde odstępstwo od swobody jest zgubne dla samej sprawy oświaty ${ }^{32}$.

${ }^{29}$ Tamże, s. 426-427.

${ }^{30}$ L. Tołstoj, Nauczanie poglądowe (fragment artykutu "O społecznej działalności na polu oświaty ludowej"), [w:] L. Tołstoj, Pisma pedagogiczne, s. 267.

${ }^{31}$ L. Tołstoj, O oświacie ludowej (list do J.M. Szatiłowa), [w:] Tamże, s. 388.

${ }^{32}$ L. Tołstoj, O swobodnej szkole (fragment listu do P.I. Biriukowa), [w:] Tamże, s. 424. 
Dlatego, promując Swobodne Wychowanie, Tołstoj bez ogródek wskazywał na wady i niedociągnięcia procesu pedagogicznego, które czynią go w rażący sposób nieskutecznym, a nawet uwsteczniającym rozwój uczniów. Piętnował zatem jawne lekceważenie indywidualnych zainteresowań i potrzeb dzieci, niezwracanie uwagi na ich charakter i cechy indywidualne, tworzenie bezdusznych i formalistycznych metod nauczania, nieuwzględnianie warunków panujących w rodzinach dzieci oraz warunków ich pracy w domu.

Wystarczy spojrzeć na samo dziecko w domu, na ulicy lub w szkole - raz widzimy istotę pełną radości, życia i zainteresowań, z uśmiechem w oczach i na ustach, wszędzie szukającą wiedzy jak radości, wyraźnie i często wypowiadającą swe myśli we własnym języku, to znów widzimy istotę udręczoną i skurczoną, z wyrazem zmęczenia, strachu i nudy, (...) istotę, której dusza jak ślimak schowała się do własnego domku. Wystarczy zaobserwować te dwa stany, aby zdecydować, że który z nich jest pożyteczniejszy dla rozwoju dziecka. Ten dziwny stan psychiczny, który nazywamy szkolnym stanem duszy, (...) polega na tym, że wszystkie zdolności wyższe - wyobraźnia, twórczość, pojętność - ustępują miejsca jakimś innym zdolnościom, na wpół zwierzęcym (...), jednym słowem - zdolnościom dławienia w sobie wszystkich zdolności wyższych w celu rozwoju tylko takich, jak: strach, wytężona pamięć i uwaga, które odpowiadają stanowi szkolnemu. Każdy uczeń dopóki nie podda się trybom tego na wpół zwierzęcego stanu, jest do szkoły disparate [niedopasowany - przyp. aut.]. Skoro zaś dziecko dojdzie już do tego stanu, iż utraci całą swoją swobodę i samodzielność, skoro już tylko zaczną się uwidaczniać różne objawy choroby - obłuda, bezcelowe kłamstwo, tępota itp. - nie jest ono już disparate w szkole, weszło w jej tryby i nauczyciel zaczyna być z niego zadowolony. Wtedy także zjawiają się te nie przypadkowe, ale stale powtarzające się zjawiska, iż dziecko najgłupsze jest uczniem najlepszym, a najmądrzejsze najgorszym ${ }^{33}$.

\section{Tołstoj wzywa zatem:}

Uświadomijmy sobie wreszcie to prawo, które tak wyraźnie wynika i z historii pedagogiki, i z historii całej oświaty, że po to, by oświecający wiedział, co jest dobre, a co złe, oświecany musi mieć pełną możliwość wyrażania swego niezadowolenia albo przynajmniej uchylania się od takiej oświaty, która instynktownie nie zadowala go, oraz że kryterium, które dyktuje pedagogika, jest tylko jedno - swoboda ${ }^{34}$.

Pozostając pod przemożnym wpływem Rousseau, Tołstoj był głęboko przekonany, że dzieci przynoszą ze sobą na świat tylko pozytywne zadatki i dają pełną gwarancję realizacji najbardziej doskonałego procesu pedagogicznego. Dążenie dorosłych do oddziaływania wychowawczego na dzieci tłumaczył uczuciem zawiści zepsutych ludzi w stosunku do czystych, nie-

\footnotetext{
33 L. Tołstoj, O oświacie ludowej, s. 24-25.

${ }_{34}$ Tamże, s. 35.
} 
winnych dzieci ${ }^{35}$. Takie wychowanie - stwierdza Tołstoj - „wypacza, a nie poprawia ludzi"36.

Fundamentalną rolę $\mathrm{w}$ procesie wychowawczym przypisywał Tołstoj postawie nauczyciela. Chociaż uważał, że proces pedagogiczny ma przede wszystkim charakter poznawczy, a nie wychowawczy ${ }^{37}$, stosunek nauczyciela do uczniów, jego zapał i poświęcenie ma ogromny wpływ wychowawczy.

Nauka - pisał Tołstoj - jest nauką i niczego w sobie nie zawiera. Element zaś wychowawczy tkwi w nauczaniu, w miłości nauczyciela do własnej nauki i w przekazywaniu jej z miłością uczniom. Chcesz przez naukę wychować ucznia, kochaj swą naukę i znaj ją, a uczniowie polubią i ciebie, i naukę, i ty ich wychowasz; ale jeżeli sam jej nie lubisz, to bez względu na to, ile byś kazał się uczyć, nauka nie wywrze na nich wpływu wychowawczego. (...) Istnieje tylko jeden sprawdzian tego, jedna droga - znowu ta sama wolna wola uczniów ${ }^{38}$.

Relacja między uczniem a nauczycielem powinna więc opierać się na zaufaniu.

Nikt, prawdopodobnie, nie będzie mógł przeczyć, iż najlepsze stosunki pomiędzy nauczycielem i uczniami, to stosunki zaufania i że przeciwieństwem stosunków zaufania są stosunki przymusu. Jeżeli tak jest w istocie, to miernikiem wartości wszystkich metod jest większy lub mniejszy stopień zaufania, względnie większy lub mniejszy stopień przymusu stosowanego wobec dzieci w procesie nauczania ${ }^{39}$. Tymczasem stwierdza - szkołę urządza się nie tak, aby dzieciom było dobrze się uczyć, lecz tak, aby nauczycielom było wygodnie uczyć. Dla nauczyciela niewygodne są rozmowy, ruch, radość dzieci, co stanowi dla nich niezbędne warunki nauki, dlatego w szkołach zbudowanych jak więzienia zakazane są pytania, rozmowy, ruch. Zamiast przekonać się, iż aby skutecznie oddziaływać na jakiś przedmiot, należy go poznać (a przedmiotem wychowania jest nieskrępowane dziecko), nauczyciele chcą uczyć tak, jak umieją, jak im się zamarzy, przy niepowodzeniu zaś gotowi są zmienić nie sposób nauczania, ale naturę dziecka (...). Każda nauka winna być jedynie odpowiedzią na pytania, które stawia życie. Tymczasem szkoła nie tylko nie pobudza do pytań, lecz nawet nie odpowiada na te, które rodzi życie. Ona stale odpowiada na te same pytania, które od wieków temu wstecz wysunęła ludzkość, a nie wiek dziecięcy, a które dziecko nic a nic nie obchodzą ${ }^{40}$.

Tołstoj stawiał zatem nauczycielom wysokie wymagania i oczekiwał, że będą przyjaciółmi dzieci. Uważał, że najistotniejsze w pracy nauczyciela

${ }^{35}$ L. Tołstoj, Kto u kogo ma się uczyć pisać: dzieci chtopskie u nas, czy my u dzieci chłopskich, [w:]

L. Tołstoj, Pisma pedagogiczne, s. 338-340.

${ }^{36}$ Tamże, s. 340.

${ }^{37}$ L. Tołstoj, Wychowanie a wykształcenie, s. 258.

${ }^{38}$ Tamże, s. 261.

39 Tamże.

${ }^{40}$ L. Tołstoj, O oświacie ludowej, s. 23-24. 
jest działanie na rzecz rozwoju osobowości dziecka, uzbrojenie go w wiedzę i umiejętności niezbędne w życiu oraz pobudzenie jego twórczych sił. Nie da się tego osiągnąć bez autentycznego powołania, które rozumiał jako miłość do dzieci i gotowość do swoistej kenosis, czyli zejścia do poziomu dziecka, aby je poznać. Zamiast konformizmu i formalistycznego traktowania dzieci usiłował Tołstoj wnieść do pracy nauczycielskiej elementy twórczego wysiłku i zachęcał nauczycieli do samokształcenia, aby uczyli się dostosowywać ogólne wskazania metodyczne do konkretnych warunków procesu pedagogicznego. Jako redaktor i wydawca czasopisma pedagogicznego Jasna Polana wzywał nauczycieli do wnikliwego zbierania doświadczeń i publikowania swoich spostrzeżeń na jego łamach. Jego zdaniem, szczery opis doświadczenia, ze wszystkimi wahaniami, zmianami, niepowodzeniami oraz błędami jest bardziej pouczający i ma większą wartość dla nauki niż wyłożenie rzekomo nieomylnej metody. Artykuły sprawozdawcze Tołstoja o pracy założonej przez niego szkoły są tego doskonałym przykładem ${ }^{41}$.

Najlepszym nauczycielem będzie taki nauczyciel, który natychmiast potrafi wyjaśnić to, co zajmuje ucznia. (...) Winien dobrze znać i w praktyce swojej wypróbować jedną, wypracowaną przez naród metodę; winien jednak starać się poznać jak najwięcej metod, traktując je jako środki pomocnicze; winien on każdą trudność, jaką napotyka uczeń w rozumieniu, uważać nie za wadę ucznia, lecz za wadę swojego nauczania oraz starać się rozwijać w sobie zdolność wykrywania nowych sposobów pracy. Nauczyciel musi wiedzieć, że każda wynaleziona metoda to tylko szczebel, który osiągnął po to, aby iść dalej².

Oczywiście, Tołstoj nie miał złudzeń, że jego wizja pedagogiki zostanie entuzjastycznie przyjęta. Historia szkoły w Jasnej Polanie, która działała tylko trzy lata, oraz los wydawanego przez niego czasopisma, które już po roku zostało zamknięte, są tego dostatecznym dowodem. Śledząc rozwój i kierunek myśli pedagogicznej Tołstoja, można zauważyć, że kierował się on często wymaganiami zdrowego rozsądku, a nie dowodami naukowymi czy filozoficznymi.

Wiem, - pisał - że mój wywód niewielu przekona. (...) Wiem, że moje zasadnicze twierdzenia, że jedyną metodą kształcenia jest doświadczenie, a jedynym jego kryterium - swoboda, niektórym wydadzą się wyświechtanym banałem. Nie odważyłbym się zakłócać spokoju pedagogów-teoretyków i głosić poglądów tak bardzo sprzecznych z opinią całego świata, gdybym mógł ograniczyć się tylko do niniejszych rozważań (...). Czuję jednak, że jestem w stanie krok za krokiem, na podstawie faktów, udowodnić realność i słuszność moich tak szalonych twierdzeńn ${ }^{43}$.

\footnotetext{
${ }^{41}$ L. Tołstoj, Szkoła jasnopolańska, s. 126-222.

${ }^{42}$ L. Tołstoj, O metodach nauki czytania i pisania, [w:] L. Tołstoj, Pisma pedagogiczne, s. 63.

${ }^{43}$ L. Tołstoj, O oświacie ludowej, s. 36-37.
} 
Biorąc pod uwagę fakt, że twórczość i aktywność Lwa Tołstoja jako pedagoga na trwałe weszła do skarbnicy klasyków myśli pedagogicznej, wypada stwierdzić, że głoszone przez niego idee wytrzymały próbę czasu i okazały się inspirujące nie tylko dla wielu mu współczesnych, ale znajdują odzwierciedlenie we współczesnych rozwiązaniach dydaktyczno-wychowawczych wielu szkół demokratycznych. Chociaż - jak zauważa Michał Szulkin - „poglądy pedagogiczne Tołstoja nie tworzą jednolitego i konsekwentnego systemu, nie są pozbawione sprzeczności i wahań", to jednak wywarły znaczący wpływ nie tylko na rosyjską, ale także światową myśl pedagogiczną ${ }^{44}$. Nie mogli jej pominąć ani wielbiciele, którzy uważali Lwa Tołstoja za mistrza i bogobojnego starca $^{45}$, jak i wrogowie, dla których był niepokornym heretykiem i „fałszywym prorokiem" ${ }^{\prime 46}$. Tym bardziej, w dobie obecnego renesansu myśli pedagogicznej Nowego Wychowania, ich przypomnienie wydaje się celowe i potrzebne.

\section{BIBLIOGRAFIA}

Demolins E., Nowe wychowanie, przekł. J.W. Dawid, Nakładem Księgarni E. Wende i S-ki, Warszawa 1900.

Dewey J., My Pedagogic Creed, E.L. Kellogg \& Co., New York - Chicago 1897.

Edukacja alternatywna w XXI wieku, red. B. Śliwerski, Z. Melosik, Oficyna Wydawnicza Impuls, Kraków 2013.

Gonczarow N.K., Oświata i wychowanie w Rosji na początku drugiej połowy XIX w., [w:] Historia wychowania, t. II, red. Ł. Kurdybacha, Państwowe Wydawnictwo Naukowe, Warszawa 1967.

Hessen S., Podstawy pedagogiki, przekł. A. Zieleńczyk, Wydawnictwo Akademickie Żak, Warszawa 1997.

Key E., Stulecie dziecka, przekł. I. Moszczyńska, Nakładem Księgarni Naukowej, Warszawa 1907.

Kot S., Historia wychowania, t. II, Wydawnictwo Akademickie Żak, Warszawa 1996.

Kupisiewicz C., Szkoła w XX wieku, Wydawnictwo Naukowe PWN, Warszawa 2006.

Legowicz J., Pedagogika francuskiego naturalizmu, [w:] Historia wychowania, t. I, red. Ł. Kurdybacha, Państwowe Wydawnictwo Naukowe, Warszawa 1967.

Nabokov V., Wykłady o literaturze rosyjskiej, przekł. Z. Batko, Wydawnictwo Literackie Muza, Warszawa 2002.

Nowakowska-Siuta R., Stowo wstępne, [w:] Edukacja alternatywna na rzecz demokratyzacji procesu kształcenia, red. R. Nowakowska-Siuta, Oficyna Wydawnicza Impuls, Kraków 2014.

Sośnicki K., Rozwój pedagogiki zachodniej na przełomie XIX i XX wieku, Państwowe Zakłady Wydawnictw Szkolnych, Warszawa 1967.

${ }^{44}$ M. Szulkin, Wstęp, [w:] L. Tołstoj, Pisma pedagogiczne, s. XXXV-XXXVI.

${ }^{45}$ V. Nabokov, Wykłady o literaturze rosyjskiej, przekł. Z. Batko, Warszawa 2002, s. 188.

46 Определение Святейшего Синода от 20-22 февраля 1901 года, с посланием верным чадам православныя грекороссийския церкви о графе Льве Толстом, Церковные ведомости, издаваемые при Святейшем Правительствующем Синоде, 24 февраля 1901, 8, s. 45-47. 
Sztobryn S., Filozofia wychowania Sergiusza Hessena, Wydawnictwo Uniwersytetu Łódzkiego, Łódź 1994.

Sztobryn S., Pedagogika Nowego Wychowania, [w:] Pedagogika. Podręcznik akademicki, t. I, red. Z. Kwieciński, B. Śliwerski, Wydawnictwo Naukowe PWN, Warszawa 2005.

Szulkin M., Wstęp, [w:] L. Tołstoj, Pisma pedagogiczne, przekł. L. i S. Wołoszynowie, Zakład Narodowy Imienia Ossolińskich - Wydawnictwo Polskiej Akademii Nauk, Wrocław - Warszawa - Kraków 1963.

Tołstoj L., Kto u kogo ma się uczyć pisać: dzieci chłopskie u nas, czy my u dzieci chtopskich, [w:] L. Tołstoj, Pisma pedagogiczne, przekł. L. i S. Wołoszynowie, Zakład Narodowy Imienia Ossolińskich - Wydawnictwo Polskiej Akademii Nauk, Wrocław - Warszawa - Kraków 1963.

Tołstoj L., Nauczanie pogladowe (fragment artykutu "O społecznej działalności na polu oświaty ludowej"), [w:] L. Tołstoj, Pisma pedagogiczne, przekł. L. i S. Wołoszynowie, Zakład Narodowy Imienia Ossolińskich - Wydawnictwo Polskiej Akademii Nauk, Wrocław - Warszawa - Kraków 1963.

Tołstoj L., O metodach nauki czytania i pisania, [w:] L. Tołstoj, Pisma pedagogiczne, przekł. L. i S. Wołoszynowie, Zakład Narodowy Imienia Ossolińskich - Wydawnictwo Polskiej Akademii Nauk, Wrocław - Warszawa - Kraków 1963.

Tołstoj L., O oświacie ludowej (list do J.M. Szatiłowa), [w:] L. Tołstoj, Pisma pedagogiczne, przekł. L. i S. Wołoszynowie, Zakład Narodowy Imienia Ossolińskich - Wydawnictwo Polskiej Akademii Nauk, Wrocław - Warszawa - Kraków 1963.

Tołstoj L., O oświacie ludowej, [w:] L. Tołstoj, Pisma pedagogiczne, przekł. L. i S. Wołoszynowie, Zakład Narodowy Imienia Ossolińskich - Wydawnictwo Polskiej Akademii Nauk, Wrocław - Warszawa - Kraków 1963.

Tołstoj L., O społecznej działalności na polu oświaty ludowej, [w:] L. Tołstoj, Pisma pedagogiczne, przekł. L. i S. Wołoszynowie, Zakład Narodowy Imienia Ossolińskich - Wydawnictwo Polskiej Akademii Nauk, Wrocław - Warszawa - Kraków 1963.

Tołstoj L., O swobodnej szkole (fragment listu do P.I. Biriukowa), [w:] L. Tołstoj, Pisma pedagogiczne, przekł. L. i S. Wołoszynowie, Zakład Narodowy Imienia Ossolińskich - Wydawnictwo Polskiej Akademii Nauk, Wrocław - Warszawa - Kraków 1963.

Tołstoj L., O wychowaniu (odpowiedź na list W.F. Bułgakowa), [w:] L. Tołstoj, Pisma pedagogiczne, przekł. L. i S. Wołoszynowie, Zakład Narodowy Imienia Ossolińskich - Wydawnictwo Polskiej Akademii Nauk, Wrocław - Warszawa - Kraków 1963.

Tołstoj L., Ogólne uwagi dla nauczyciela, [w:] L. Tołstoj, Pisma pedagogiczne, przekł. L. i S. Wołoszynowie, Zakład Narodowy Imienia Ossolińskich - Wydawnictwo Polskiej Akademii Nauk, Wrocław - Warszawa - Kraków 1963.

Tołstoj L., Postęp a definicja wykształcenia, [w:] L. Tołstoj, Pisma pedagogiczne, przekł. L. i S. Wołoszynowie, Zakład Narodowy Imienia Ossolińskich - Wydawnictwo Polskiej Akademii Nauk, Wrocław - Warszawa - Kraków 1963.

Tołstoj L., Rola przykładu i naśladownictwa w wychowaniu, [w:] L. Tołstoj, Pisma pedagogiczne, przekł. L. i S. Wołoszynowie, Zakład Narodowy Imienia Ossolińskich - Wydawnictwo Polskiej Akademii Nauk, Wrocław - Warszawa - Kraków 1963.

Tołstoj L., Szkoła jasnopolańska w miesiacu listopadzie i grudniu, [w:] L. Tołstoj, Pisma pedagogiczne, przekł. L. i S. Wołoszynowie, Zakład Narodowy Imienia Ossolińskich - Wydawnictwo Polskiej Akademii Nauk, Wrocław - Warszawa - Kraków 1963.

Tołstoj L., Wychowanie a wykształcenie, [w:] L. Tołstoj, Pisma pedagogiczne, przekł. L. i S. Wołoszynowie, Zakład Narodowy Imienia Ossolińskich - Wydawnictwo Polskiej Akademii Nauk, Wrocław - Warszawa - Kraków 1963. 
Вентцель К.Н., Борьба за свободную школу, Типография торгового дома А.П. Печковский и А.П. Куланже, Москва 1906.

Вентцель К.Н., Как создать свободную школу (дом свободного ребенка), Типография Товарищества И. Н. Кушнеревъ и Кㅇ, Москва 1906.

Вентцель К.Н., Отделение школы от государства и декларация прав ребенка, Типография Т-ва И. Н. Кушнеревъ и К, Москва 1906.

Кей Э.К.С., Век ребенка, пер. Е. Залога, В. Шахно, Издание Д.П. Ефимова, Москва 1905.

Определение Святейшего Синода от 20-22 февраля 1901 года, с посланием верным чадам православныя грекороссийския церкви о графе Льве Толстом, Церковные ведомости, издаваемые при Святейшем Правительствующем Синоде, 24 фревраля 1901, 8.

Фомин А.Г., Педагогическая деятельность Л.Н. Толстого, [w:] Л.Н. Толстой, Педагогические сочинения, Типография акционерного общества „Слово”, С.-Петербург 1912. 